\title{
The Influence of Brand Equity on Consumer Response toward Environmental Product Advertisements
}

\author{
Brian T Parker \\ Correspondence: Brian T Parker, Florida State University, USA \\ Received: April 29, 2015 Accepted: May 14, 2015 Online Published: May 25, 2015 \\ doi:10.11114/smc.v3i1.800 URL: http://dx.doi.org/10.11114/smc.v3i1.800
}

\begin{abstract}
This study reports an examination of the relationship between a three-factor brand equity measure (brand awareness, brand quality, and brand loyalty) and consumer response toward environmental product advertisements for four brands (i.e., Whole Foods, Green Works, Prius, and Volt). An online, digital survey allowed the presentation of television commercials and accompanying response measures including green brand trust, perceived ad claim believability, and attitude-toward-the-ad. Results illustrate significant relationships between brand equity with the green trust and claim believability measures, but not with attitude toward the advertisements. Analysis also illustrated the interrelationships between the response variables and showed of the brand equity dimensions, perceived brand quality, and especially brand loyalty, had significant relationships with the green brand trust and ad claim believability measures. In addition, brand image was a significant factor only for the automobile brands, indicating a possible category effect, where this brand equity factor is relevant. Results suggest that preexistent brand dispositions influence perceived environmental ad believability and trust, critical factors, which have a significant influence on message effectiveness.
\end{abstract}

Keywords: brand equity (consumer), brand awareness, brand loyalty, perceived brand quality, brand evaluation, environmental marketing, green advertising

\section{Introduction}

This study looked at the relationship between brand equity and consumer response toward environmental product advertisements. Specifically, the research goal was to examine the influence of preexistent brand dispositions, via the brand equity construct, on consumers' perceived credibility and trust of environmental advertisement claims. Advertisement credibility is "the extent to which the audience perceives claims made about the brand in the ad to be truthful and believable" (Lutz, 1985, p.49). If an individual does not believe the message claim in an advertisement to be truthful, the chance of that ad eliciting the intended response is greatly diminished. Perceived claim believability has a strong influence on message effectiveness and compliance (Beltramini \& Evans, 1985; O'Cass \& Griffin, 2008), and increases the chance that an individual will develop beliefs congruent with the ad message (Obermiller \& Spangenberg, 1998).

Advertiser reputation has an influence on perceived ad credibility similar to that of spokesperson or endorser credibility (Goldberg \& Hartwick, 1990). When consumers are familiar with a company, they likely have already developed perceptions of its credibility that mediate response to its advertisements. Newell (1993) showed that corporate credibility positively relates to brand and advertisement attitude formation. Goldsmith, Lafferty and Newell (2000, p.46) argue that, "knowledge about the brand makes up part of the information consumers use to evaluate new information they receive about the brand" in advertisements, and illustrated the direct relationship of corporate credibility on ad response. Ultimately, the brand name embodies this reputation, which is the part of a brand apart from other identifiers (e.g., logos), that can be vocalized, and is the primary indicator of brand value (Cobb-Walgreen, Ruble, \& Donthu, 1995).

Brand equity represents attitudes and perceptions that exist prior to ad exposure and are reflective of experiences with the brand, past exposure to the brand or marketing information regarding the brand, as well as involvement in the product category. Brands are one of the most recognizable and important influencers of consumer behavior. Well-known, strong brands instill consumer trust and confidence that helps reduce purchase risk and simplify decisions. Brand equity is the value added to a firm and its product because of the good will and loyalty consumers have toward the brand, and similar to corporate credibility has an influence on marketing communications. This study examined the anteceding 
influence of brand equity on environmental ad response, particularly levels of trust and believability of message claims.

\subsection{Brand Equity}

Aaker (1991, p. 15) theoretically defined brand equity as "a set of brand assets and liabilities linked to a brand, its name and symbol, that add to or subtract from the value provided by a product or service to a firm and/or to that firm's customers." Aaker $(1991,1996)$ further devised a five factor model of the brand equity construct that includes name awareness, brand associations, perceived quality, brand loyalty, and other proprietary assets (e.g., patents). Aaker's model is a "composite of important consumer behavior variables" (Ross, 2006, p. 23), and has been a leading paradigm in brand equity research. In addition, researchers have developed a number of valid, reliable measures of the construct dimensions (Keller, 1993; Park \& Srinivasan, 1994; Yoo \& Donthu, 2001; Zeithaml, 1988).

Employed in this study are Yoo and Donthu's (2001) 'customer-based' brand equity scales, developed to measure four of the five (i.e., excluding other proprietary assets) factors in Aaker's model. A customer-based conceptual approach indicates brand equity facets that affect customer behavior, typically using survey research to measure responses attributed to the brand name. Keller $(1993$, p. 8) originated the concept 'customer-based' brand equity (CBBE) as a theory of understanding brand equity at the individual consumer level rather than using other methods (e.g., financial indicators or market share) of brand valuation.

Brand name awareness and brand associations are related memory constructs, but are theoretically distinct. Brand name awareness is the strength of a brand's presence in consumer memory (i.e., recognition and recall), a necessary condition for brand equity development on the other three dimensions (Keller, 1993). Awareness is a continuum that ranges from completely unaware to top-of-mind awareness. Importantly, high brand awareness does not always denote high brand equity; poor performance brands can also have high recognition and recall. In contrast, brand associations are pieces of positive and negative information related to a brand in consumer memory. Brand associations are critical in the overall management function of branding because they represent the content of brand knowledge and provide brand meaning to consumers (Keller, 1993).

Perceived brand quality is the consumer's subjective judgment about a brand's overall excellence (Aaker, 1996; Zeithaml, 1988), is an important point of differentiation (Aaker, 1996), and is the only brand equity dimension statistically demonstrated to drive sales performance and predict return on investment. Importantly, as perceptions of brand quality improve, other brand perceptions also improve (Zeithaml, 1988). Brand loyalty is the level of attachment that a customer has to a brand, considered the single most reliable assessment of brand equity (Reichheld, 2001). Loyal consumers provide companies a competitive advantage that helps establish barriers of entry, gives companies time to respond to competitive offerings, and allows the demanding of premium prices (Aaker, 1996). Consumer loyalty ultimately results from value and trust derived from the brand name (Chaudhuri \& Holbrook, 2001; Riley, 2004).

\subsection{Current Brand Equity Research}

Aaker's (1996) four-factor CBBE model pervades current brand equity literature and research (e.g., see Allaway, Huddleston, Whipple, \& Ellinger, 2011; Boo, Busser, \& Baloglu, 2009; Chen \& Tseng, 2010; Parker, 2012; Tong \& Hawley, 2009; Yasin \& Zahari, 2011). Scholars have employed Aaker's model in a variety of unique marketing contexts, and have studied the inter-relationships amongst the four brand equity dimensions, illustrating the usefulness of each factor in brand equity development.

For example, Allaway et al., 2011 applied the four-factor model in a study of supermarket brand equity, illustrating brand loyalty and quality to be significant drivers of high brand equity. Rios and Riquelme (2008) illustrated CBBE's application for online brands, demonstrating that brand loyalty and brand associations are important for establishing online brand equity, while brand awareness had an indirect influence for online brands. Juntunen, et al., 2011 evidenced a significant relationship between CBBE and corporate brand equity in a study of B2B brands. Study findings suggest that corporate brand associations (i.e., corporate image and reputation) are central to corporate brand equity, showing that brand loyalty is an outcome of a strong, favorable corporate image.

\subsection{Inter-Relationships between Brand Equity Factors}

A path analysis study of airline brand equity looked at the inter-relationships between the four CBBE factors and their individual contribution to overall brand equity (Chen \& Tseng, 2010). Findings demonstrated that brand loyalty had the only significant, direct path with overall CBBE, while the other three factors (i.e., brand awareness, brand image, and perceived brand quality) had indirect relationships with overall airline brand equity. Severi and Choon Ling (2013) also examined the inter-relationships amongst the four CBBE factors, showing how particular factors mediate the influence of other factors when developing overall brand equity (e.g., brand associations mediate the relationship between brand awareness and brand equity, while brand loyalty mediates the relationship between brand associations and brand equity). Such studies indicate dynamic relationships between the four CBBE dimensions. 


\subsection{Environmental Product Advertisements}

An environmental (a.k.a. green) 'product' advertisement implies a distinction from other forms of environmental communication that do not have the goal of selling product, such as Public Service Announcements or other social awareness campaigns. An environmental ad meets at least one of the following criteria: (1) an ad that explicitly or implicitly addresses the relationship between a product/service and the biophysical environment, (2) ad promotes a green lifestyle with or without highlighting a product/service, or (3) ad presents a corporate image of environmental responsibility (Banerjee, Gulas, \& Iyer, 1995).

Stisser (1994) illustrated that environmental associations improve attitude toward particular brands, however, in general they are secondary when consumers evaluate purchase alternatives. Schlossberg (1991) showed that while the environment rates important to many consumers, this only transferred to purchase behavior for small niche markets. However, as environmental awareness diffuses through the consumer population, researchers have cataloged a parallel shift in favorable attitudes toward brands perceived as good for the environment (Hartmann, Ibanez, \& Sainz, 2005).

The concepts of trust and perceived believability are particularly important for environmental advertising because individuals have grown skeptical toward green marketing efforts due to factors such as 'green-washing' (i.e., shallow, disingenuous environmental claims) and overuse of green symbolism for marketing products (Banerjee, Gulas \& Iyer, 1995; Karna \& Heikki, 2001; Zinkhan \& Carlson, 1995). An analysis of green advertisements confirms that most attempts to communicate a green position were shallow, focusing on an image of "corporate environmental responsibility", with little involvement in substantial environmental issues (Banerjee, Gulas, \& Iyer, 1995). The Federal Trade Commission (FTC) regularly updates regulations intended to halt exploitative green marketing and reverse the trend of consumer mistrust toward environmental claims (Federal Trade Commission [FTC], 2012).

\subsection{Green Brand Trust}

Grant (2008, p. 25) defined a green brand as "one that offers a significant eco-advantage over the incumbents", though the term refers to a range of brand positions such as environmental, eco-friendly, energy efficient, and organic. Brand trust is a consumer's "willingness to rely on the brand in the face of risk because of expectations that the brand will cause a positive outcome" (Lau, p.344), or the confidence in the brand's reliability and intention (Delgado, 2003). Green brand trust (GBT), a subset of brand trust specific to green/environmental context, is a concept introduced by Chen (2009, p. 312), defined as the confident expectations of the consumer to "depend on a brand based on the belief or expectation resulting from its credibility, benevolence, and ability about its environmental performance".

\subsection{Research Agenda}

This study's overall purpose was to examine the relationship between customer-based brand equity (CBBE) and consumer response toward environmental advertisements, including perceived environmental claim credibility and attitude-toward-the advertisement. The latter, ad credibility consisted of two constructs employed to capture consumer trust and believability of the ads' environmental claims. Attitude-toward-the-ad provided an overall evaluation of the ad and a benchmark to examine the other study variables. The first three hypotheses (1-3) propose positive relationships between brand equity and the environmental ad response variables. The central proposition tested is that higher equity brands will garner higher levels of trust and believability toward environmental message claims because of the inherent confidence instilled by strong brands. The latter three hypotheses (4-6) propose positive relationships between the post-ad exposure response variables (i.e., green brand trust, perceived believability, and attitude-toward-the-ad).

HO$_{1}$ : There will be a positive relationship between customer-based brand equity (CBBE) and green brand trust toward the brand's environmental advertisement claims.

$\mathrm{HO}_{2}$ : There will be a positive relationship between customer-based brand equity (CBBE) and the perceived believability of the brand's environmental advertisement claims.

$\mathbf{H O}_{3}$ : There will be a positive relationship between customer-based brand equity (CBBE) and attitude toward the brand's environmental advertisement.

$\mathbf{H O}_{4}$ : There will be a positive relationship between green brand trust and perceived environmental ad claim believability.

HO$_{5}$ : There will be a positive relationship between green brand trust and attitude toward the advertisement.

HO$_{6}$ : There will be a positive relationship between perceived environmental ad claim believability and attitude toward the advertisement.

This study also looked at the relationships between each individual factor of the multi-dimensional brand equity construct (i.e., perceived quality, brand image strength, and brand loyalty) with perceived ad credibility factors (i.e., green brand trust and claim believability) and attitude toward environmental product ads. The CBBE measures tap 
three important consumer behavior domains: memory (i.e., image strength), perception (i.e., quality valuation), and attitudinal (i.e., loyalty) domain, factors that influence the persuasive effectiveness of advertisements and other forms of marketing communication. The research goal was to determine which of the three brand equity factors has the strongest relationship with the three ad response variables for environmental ads that make green brand claims.

\section{Method}

\subsection{Participants}

The sample included one hundred forty three $(n=143)$ U.S. adult (aged 18-64 years) consumers primarily from the South and Southwest regions, with a small portion from other regions. Respondents' age averaged thirty-two years, split 60 percent females $(n=86), 38$ percent males $(n=54)$, and 2 percent did not record their sex. Yearly household income averaged between 50,000 to 59,999 dollars. The sample was multiethnic including Caucasian, Asian/Pacific Islander, Hispanic/Latino, African/Black, Native American, Brazilian, and Italian respondents.

\subsection{Procedures}

This study used a survey executed via a web-based questionnaire, developed with Qualtrics Research Suite, a service that provides a range of design, analysis, and data security options for conducting online research. The survey software provided the ability to display television / video advertisements in the context of the survey questions and scales. The questionnaire presented each brand individually with a familiarity measure to ensure respondents did not respond to an unknown brand. If familiar with a brand, skip logic progressed respondents to the brand equity measures. After assessing a brand's equity, respondents viewed the brand's environmental advertisement and then responded on green brand trust (GBT), perceived claim believability, and attitude-toward-the-ad $\left(\mathrm{A}_{\mathrm{ad}}\right)$ measures described below. The survey software randomized brand presentation to eliminate order bias effects. The final section of the questionnaire collected basic demographics.

Four brands served as units of analysis: Green Works, Whole Foods, Toyota Prius, and Chevrolet Volt. These brands were selected for the study because (1) they make green product offerings (2) each had environmental or green product ads available for analysis, and (3) each deemed likely to be familiar to respondents. Ads were television commercials, in a common file format uploaded to the online questionnaire. A convenience sample, derived from the general consumer population using recruitment techniques through social networking cites (i.e., Facebook, MySpace, and Twitter) and supplemented with students from a large southeastern university served as study respondents. Most respondents (i.e., 83 percent) were non-students. Target respondents received an automated email invitation briefly explaining general study aims, an incentive to win one of three cash prizes, and a hyperlink for the questionnaire URL.

\subsection{Data Collection Instruments}

Yoo and Donthu (2001, p.2) developed a series of validated psychometric scales that measure customer-based brand equity, conceptualized as the "measurement of cognitive and behavioral brand equity at the individual consumer level through a consumer survey." The multidimensional brand equity (MBE) scale is a three-factor model that combines 'recognition awareness' and 'perceptual strength of associations' into one memory-based factor, while treating perceived quality and brand loyalty as independent factors. Hence, the combined memory dimension is referred to as 'brand awareness-association strength' from this point forward to facilitate discussion.

The MBE measure contains two items for brand awareness (I am aware of 'brand x' and "I can recognize 'brand x' among other competing brands") and three items for brand image strength ("some characteristics of 'brand x' come to my mind quickly," "I can quickly recall the symbol or logo of 'brand x'," and "I have difficulty in imagining "brand x' in my mind"). Perceived brand quality contains two items ("the likelihood that 'brand x' would be a quality product is extremely high," and "the likelihood that 'brand x' would be a functional product is extremely high"), and three items for brand loyalty ("I consider myself loyal to "brand x'," "brand x would be my first choice," and "I will not purchase another brand if 'brand $\mathrm{x}$ ' is available).

Respondents indicated their agreement to each MBE item statement using 5-point Likert scales that ranged from completely disagree (1) to completely agree (5). Averaged items for each scale dimension produce an awareness-association strength score, a perceived brand quality score, and a brand loyalty score for each analyzed brand. Total brand equity rating is the average of dimension scores across all scaled items.

The green brand trust scale (Chen, 2009) had five items (i.e., you feel that 'brand x's' environmental commitments are generally reliable, you feel that 'brand x's' environmental performance is generally dependable, you feel that 'brand x's' environmental argument is generally trustworthy, 'brand x's' environmental concern meets your expectations, and 'brand $\mathrm{x}$ ' keeps promises and commitments for environmental protection). Respondents indicated agreement with each statement using 5-point Likert scales that ranged from completely disagree (1) to completely agree (5). 
Perceived environmental advertisement believability was operationalized with 5-point bipolar adjective scales with items (i.e., believable/unbelievable, convincing/not convincing, credible/not credible, reasonable/ unreasonable) developed by Beltramini and Evans (1985). Attitude-toward-the-ad (Aad) was operationalized with three evaluative semantic differential item pairs (good/bad, favorable/unfavorable, positive/negative), also using 5-point scales to maintain consistency across measures. The attitude measure gauged general ad attitude without addressing other factors that might underlie the evaluation.

\section{Results}

\subsection{Correlations and Descriptive Statistics for Study Variables}

Tables 1-4 display the correlations among and descriptive statistics for the multidimensional brand equity (MBE), green brand trust (GBT), perceived ad claim believability $(\mathrm{AB})$, and attitude-toward-advertisement $\left(\mathrm{A}_{\mathrm{ad}}\right)$ measures for each analyzed brand. For the four brands, Cronbach's Alpha reliability coefficients were as follows for each scale: GBT scale items ranged between .908 and $.961, \mathrm{AB}$ scale items ranged between .825 and .919 , and $\mathrm{A}_{\text {ad }}$ items ranged between .876 and .946 . For the MBE measure, Alphas are reported for each independent factor (brand quality $=.704$ to .781 ; image strength $=.688$ to .753 ; and brand loyalty $=.759$ to .826 ).

The correlation results in row one (i.e., MBE) for each brand in Tables 1-4 illustrate findings for hypotheses 1-3 that examined the relationship between brand equity on GBT, $\mathrm{AB}$, and $\mathrm{A}_{\mathrm{ad} .}$. Overall, the brand equity measure was positively related to $\mathrm{GBT}$ and $\mathrm{AB}$ for each brand; except for Whole Foods, MBE was not significantly related to $\mathrm{AB}$. The significant correlations between MBE and GBT ranged from .31 to .53. The correlations between MBE and AB ranged from .30 to .42 for the three significant relationships. These findings provide support for hypotheses 1 and 2 , suggesting that customer-based brand equity is related to green brand trust and perceived claim believability post ad-exposure. However, in regards to hypothesis 3 , brand equity was not related to attitude-toward-the advertisement for any of the analyzed brands. Hence, findings do not support hypothesis 3 .

The correlation results in rows three and four (i.e., GBT and AB) for each brand in Tables 1-4 illustrate results that address hypotheses 3-6. GBT was significantly related to $A B$ for three of the four brands, with correlations that ranged from .29 to .47 . GBT was not significantly related to $\mathrm{AB}$ for the brand Volt. Hence, these findings provide partial support of hypothesis 4 . Similarly, GBT was significantly related to $\mathrm{A}_{\mathrm{ad}}$ for three of the four brands (excluding the brand Green Works), with significant correlations that ranged from .24 to .32, also providing partial support for hypothesis 5 . Findings support hypothesis 6 , with results illustrating that $A B$ was significantly related to $A_{\text {ad }}$ for all four brands, with correlations that ranged from .38 to 46 .

Table 1. Prius: Correlations Among and Descriptive Statistics for Study Variables

\begin{tabular}{llcccc}
\hline & $M(S D)$ & 1 & 2 & 3 & 4 \\
\hline $1 . \mathrm{MBE}$ & $3.26(.63)$ & & $.53^{* *}$ & $.34^{* *}$ & .19 \\
$2 . \mathrm{GBT}$ & $3.79(.62)$ & & & $.39^{* *}$ & $.26^{*}$ \\
$3 . \mathrm{AB}$ & $2.56(.66)$ & & & & $.38^{* *}$ \\
$4 . \mathrm{A}_{\mathrm{ad}}$ & $3.98(.77)$ & & & & \\
\hline
\end{tabular}

Notes: $N$ 's range from 144 to 146 due to occasional missing data. $\mathrm{MBE}=$ multidimensional brand equity. $\mathrm{GBT}=$ green brand trust. $\mathrm{AB}=$ perceived ad claim believability. $\mathrm{A}_{\mathrm{ad}}=$ attitude-toward-ad.

$* * p<.01 . * p<.05$.

Table 2. Volt: Correlations Among and Descriptive Statistics for Study Variables

\begin{tabular}{llllll}
\hline & $M(S D)$ & 1 & 2 & 3 & 4 \\
\hline $1 . \mathrm{MBE}$ & $2.98(.76)$ & & $.40^{*}$ & $.42^{*}$ & .05 \\
$2 . \mathrm{GBT}$ & $3.40(.54)$ & & & .07 & $.24^{*}$ \\
$3 . \mathrm{AB}$ & $2.95(.88)$ & & & & $.46^{*}$ \\
$4 . \mathrm{A}_{\mathrm{ad}}$ & $3.12(.95)$ & & & & \\
\hline
\end{tabular}

Notes: $N$ 's range from 133 to 136 due to occasional missing data and non-response. $\mathrm{MBE}=$ multidimensional brand equity. $\mathrm{GBT}=$ green brand trust. $\mathrm{AB}=$ perceived ad claim believability. $\mathrm{A}_{\mathrm{ad}}=$ attitude-toward-ad.

$* * p<.01 . * p<.05$. 
Table 3. Green Works: Correlations Among and Descriptive Statistics for Study Variables

\begin{tabular}{|c|c|c|c|c|c|}
\hline & $M(S D)$ & 1 & 2 & 3 & 4 \\
\hline 1. MBE & $3.66(.50)$ & & $.44 * *$ & $.30 *$ & .30 \\
\hline 2. GBT & $3.83(.69)$ & & & $.29 *$ & .12 \\
\hline 3. $\mathrm{AB}$ & $2.37(.69)$ & & & & $.40^{*}$ \\
\hline 4. $A_{a d}$ & $3.88(.85)$ & & & & \\
\hline
\end{tabular}

Notes: $N$ 's range from 133 to 136 due to occasional missing data and non-response. $\mathrm{MBE}=$ multidimensional brand equity. $\mathrm{GBT}=$ green brand trust. $\mathrm{AB}=$ perceived ad claim believability. $\mathrm{A}_{\mathrm{ad}}=$ attitude-toward-ad.

$* * p<.01 . * p<.05$.

Table 4. Volt: Whole Foods: Correlations Among and Descriptive Statistics for Study Variables

\begin{tabular}{llllll}
\hline & $M(S D)$ & 1 & 2 & 3 & 4 \\
\hline $1 . \mathrm{MBE}$ & $3.92(.64)$ & & $.31^{*}$ & .06 & .13 \\
$2 . \mathrm{GBT}$ & $3.81(.60)$ & & & $.47 * *$ & $.32^{*}$ \\
$3 . \mathrm{AB}$ & $2.19(.68)$ & & & & $.43^{* *}$ \\
$4 . \mathrm{A}_{\mathrm{ad}}$ & $3.71(.96)$ & & & & \\
\hline
\end{tabular}

Notes: N's range from 133 to 136 due to occasional missing data and non-response. $\mathrm{MBE}=$ multidimensional brand equity. $\mathrm{GBT}=$ green brand trust. $\mathrm{AB}=$ perceived ad claim believability. $\mathrm{A}_{\mathrm{ad}}=$ attitude-toward-ad.

$* * p<.01 . * p<.05$

\subsection{MBE Analysis}

This section of analysis examined the relationships between each brand's MBE dimension (i.e., brand image strength, perceived brand quality, and brand loyalty) scores (Table 5) with GBT and AB ratings. Whole Foods rated highest on each MBE dimension, except slightly lower $(\mu=2.70)$ on the brand loyalty rating than Green Works $(\mu=2.76)$, hence the brand's higher overall MBE score. Whole Foods was also the only brand with ratings above four for both perceived brand quality $(\mu=4.17)$ and the strength of its brand image $(\mu=4.12)$ in respondent memory.

Table 5. MBE Dimension Scores: Brand Image Strength, Perceived Brand Quality, and Brand Loyalty

\begin{tabular}{|c|c|c|c|c|c|c|}
\hline \multirow[b]{2}{*}{ Brand } & \multicolumn{2}{|c|}{$\begin{array}{c}\text { Brand Image } \\
\text { Strength }\end{array}$} & \multicolumn{2}{|c|}{$\begin{array}{c}\text { Perceived } \\
\text { Brand Quality }\end{array}$} & \multicolumn{2}{|c|}{$\begin{array}{c}\text { Brand } \\
\text { Loyalty }\end{array}$} \\
\hline & Mean & $\mathrm{SD}^{\mathrm{a}}$ & Mean & $\mathrm{SD}^{\mathrm{a}}$ & Mean & $\mathrm{SD}^{\mathrm{a}}$ \\
\hline Whole Foods & 4.12 & 0.69 & 4.17 & 0.58 & 2.70 & 0.94 \\
\hline Green Works & 3.76 & 0.56 & 3.84 & 0.43 & 2.76 & 0.82 \\
\hline Prius & 3.89 & 0.72 & 3.57 & 0.81 & 1.87 & 0.89 \\
\hline Volt & 2.88 & 1.11 & 3.33 & 0.75 & 1.94 & 1.05 \\
\hline
\end{tabular}

Note: Brand equity dimension scores are sample means of the combined scale items reported on 5-point scales $(1=$ low and $5=$ high $)$.

${ }^{\text {a }}$ Standard deviation.

Note that both automotive brands (i.e., Prius and Volt) have lower brand loyalty ratings compared to Whole Foods and Green Works, which may indicate a category effect on brand equity, particularly loyalty. Volt's MBE rating was particularly hampered from weak brand image strength $(\mu=2.88)$ relative to the other brands that were each above three on that factor.

Table 6 displays correlation results showing the relationship each MBE factor has with GBT and AB scores for the four brands. GBT was related to brand image strength for two brands (i.e., Prius and Volt), perceived brand quality for three brands (excluding Green Works), and significantly related to brand loyalty for all four brands. The strongest 
relationships were found between GBT and perceived brand quality $(r=.52)$ for Prius, and between GBT and brand loyalty $(r=.52)$ for the brand Green Works.

Table 6. Green Brand Trust (GBT) and Perceived Ad Claim Believability (AB) Correlations with MBE Dimensions

\begin{tabular}{lccc}
\hline GBT / AB & $\begin{array}{c}\text { Brand Image } \\
\text { Strength }\end{array}$ & $\begin{array}{c}\text { Perceived } \\
\text { Brand Quality }\end{array}$ & $\begin{array}{c}\text { Brand } \\
\text { Loyalty }\end{array}$ \\
\hline Whole Foods (GBT) & .11 & $.48^{* *}$ & $.28^{*}$ \\
Green Works (GBT) & .17 & .35 & $.52^{* *}$ \\
Prius (GBT) & $.43^{* *}$ & $.52^{* *}$ & $.38^{*}$ \\
Volt (GBT) & $.36^{*}$ & $.36^{*}$ & $.38^{*}$ \\
\hline Whole Foods (AB) & .10 & .17 & .07 \\
Green Works (AB) & .01 & $.45^{*}$ & $.48^{*}$ \\
Prius (AB) & $.27^{*}$ & $.25^{*}$ & $.29^{*}$ \\
Volt (AB) & $.39^{*}$ & .02 & $.40^{*}$ \\
\hline
\end{tabular}

$* * p<.01$ (2-tailed)

$* p<.05$ (2-tailed)

Perceived ad claim believability (AB) was significantly related to brand image strength for two brands (i.e., Prius and Volt), similar to GBT. AB was only significantly related to perceived brand quality for two brands (i.e., Green Works and Prius), and related to brand loyalty for three brands (excluding Whole Foods). The strongest relationships between $\mathrm{AB}$ and the MBE dimensions were both for the brand Green Works on brand quality $(r=.45)$ and brand loyalty $(r$ $=.48)$.

\section{Discussion}

Communication effectiveness often depends on consumers' prior familiarity and preexistent dispositions toward the brand advertised (Campbell \& Keller, 2003). Well-cultivated, strong brands act as beacons of trust and loyalty that facilitate positive reception and the effectiveness of marketing communication efforts (Aaker 1996; Keller 1993; Yoo \& Donthu, 2001). While a number of different factors may influence how an individual responds to an ad, when a consumer has developed affinity and loyalty toward a brand prior to ad exposure, that disposition increases favorable reactions toward subsequent advertisements (Phelps \& Thorson, 1991). This is important because according to the dual mediation hypothesis (MacKenzie, Lutz, \& Belch, 1986), favorable reactions toward an ad have a positive effect on the number of ad claims remembered and eventual purchase intentions.

This study illustrated that preexistent brand dispositions, as measured with the brand equity construct, are positively related to perceived environmental advertisement credibility, conceptualized as the extent to which respondents viewed environmental product claims as trustworthy and believable. While brand equity did not show significant relationships with attitudes toward the brands' environmental advertisements, both green brand trust and environmental ad claim belief showed significant positive relationships with attitudes toward the ads. This finding implies an indirect relationship of brand equity on the more generalized attitude measure, via its relationships with green brand trust and claim believability.

Specifically, green brand trust had significant, positive relationships with the ad attitude measure for three of the four examined brands, while perceived ad claim believability related to favorable attitudes toward the environmental ads across all brands, albeit these results do not evidence causal relationships. When consumers find claims made about a brand trustworthy and believable, not only does this influence attitudes toward the ad, but also increases the chance that an individual will remember the green claims, and develop beliefs congruent with the advertisement's message.

Furthermore, rather than use a single response metric (e.g., familiarity) to examine respondent's dispositions toward brands, this study employed a multi-factor customer-based brand equity (CBBE) construct. The CBBE construct provides a composite measure of three important domains that play an important role in the lifecycle of a brand and affect consumer behaviors: memory (brand image association strength), perception (quality valuation), and an attitudinal (loyalty) domain (Ross, 2006). Besides providing a comprehensive assessment of a brand's overall equity, the individual metrics are illustrative of which brand equity factors have stronger relationships with the advertisement outcome measures.

Of the brand equity dimensions, perceived quality and brand loyalty, particularly the latter, showed significant 
relationships with the green brand trust and ad claim believability measures. Brand loyalty was positively associated with green brand trust for all examined brands, and was positively related to environmental claim believability for all brands except for Whole Foods, whereas, perceived brand quality showed a positive relationship with green brand trust for all but one brand (i.e., Green Works), and with claim believability for all brands except Whole Foods.

In general, these results indicate that targeting environmentally positioned products toward a brand's most loyal customers may increase green ad effectiveness, and encourage other benefits that loyal customers provide, such as spreading the benefits of the product to other individuals (i.e., word-of mouth communication). In general, marketers should focus on brand quality in environmental product ads, though perceived quality may have more influence on consumers outside of loyal segments, or individuals generally skeptical toward green ad appeals.

On the other hand, the strength of brand image associations, or how well a brand is known or embedded in consumer memory, was only related to green brand trust and claim believability for the two automotive brands (i.e., Prius and Volt) green ads. This result suggests that brand image may not be as important of a factor in all environmental/green product categories. In other words, product category may moderate the role of brand equity on green brand trust and claim believability for environmentally positioned brand messages. This also further demonstrates the usefulness of using a multi-factor brand equity construct because of its inherent capacity to isolate brand factors (i.e., image vs. loyalty) that marketers should develop in order to facilitate the reception of communication promoting environmental products.

In summation, study results, while not conclusive, demonstrate that the intangible value embedded in a strong brand name (i.e., brand equity) can influence the effectiveness of environmental or green product communications by instilling higher levels of trust and belief toward green product claims. A strong brand is undoubtedly a critical marketing asset, a value that creates both an advantage for higher equity brands, and a potential communication barrier for less known and established green brands, particularly when many consumers have grown skeptical toward green product positioning and appeals. The development of sustainable, mainstream green markets may be reliant on the highest equity brands (e.g., Apple and Coca-Cola) leading the advance with environmental products that resonate with their vast audiences.

\subsection{Limitations \& Future Research}

The main limitation of this study was that it relied on a convenience sample of the general consumer population and skewed toward female $(60 \%)$ respondents, not necessarily representative of all consumers. One should not generalize the results of this study beyond the sampled respondents. Another study limitation was the reliance on psychometric measures of brand equity, and not actual behaviors (e.g., purchase a Prius or shop at Whole Foods). The use of other measures of brand equity and actual behavioral indicators may produce different results than found in the present data set.

Future research must address these issues in replication and validation studies by comparing measured results with product experience and other behavior-based assessments indicative of brand equity, while employing probability-sampling methods of different population segments. Because environmental communications do not have equal influence on all consumers, further delineation of respondents based on a range of criteria, such as age, and other demographic or psychographic criteria, would augment the present study findings.

For example, the level of consumer involvement with the environment influences the effectiveness of green communications. Schuhwerk and Lefkoff-Hagius (1995) showed that for consumers highly involved with environmental issues, support arguments in green advertisements did not influence purchase intentions and attitude toward the ads. Highly involved green consumers may be predisposed to purchase green despite the appeal. On the other hand, for consumers with low environmental involvement, green appeals were more persuasive, though they produced more counterarguments. In addition, consumers that lack environmental awareness tend to think green products are generally more expensive and do not perform well. Brand equity, particularly perceptions of brand quality, may be important for the low involved segment.

An additional study limitation was the use of four brands that do not represent the full spectrum of product categories or marketing situations. Future research should examine similar relationships found in this study across different product categories and levels of product involvement. A brand is only one aspect of a complex marketing communication situation, and subsequent research should include a variety of factors (e.g., price, dealer incentives, purchasing situations, economic conditions, etc.) as well as brand types, to provide a better understanding of how brand equity and trust can help or hinder the effectiveness of environmental product communications.

\section{References}

Aaker, D. A. (1996). Building strong brands. New York, NY: The Free Press.

Allaway, A.W., Huddleston, P., Whipple, J., \& Ellinger, A. E. (2011). Customer-based brand equity, equity drivers, and 
customer loyalty in the supermarket industry. Journal of Product and Brand Management, 20(3), 190-204. http://dx.doi.org/10.1108/10610421111134923

Banerjee, B., Gulas, C. S., \& Iyer, E. (1995). Shades of green: A multidimensional analysis of environmental advertising. Journal of Advertising, 30(1), 21-31. http://dx.doi.org/10.1080/00913367.1995.10673473

Beltramini, R. F., \& Evans, K. R. (1985). Perceived believability of research results in information in advertising. Journal of Advertising, 14, 18-31. http://dx.doi.org/10.1080/00913367.1985.10672953

Boo, S., Busser, J., \& Baloglu, S. (2009). A model of customer-based brand equity and its application to multiple destinations. Tourism Management, 30, 219-231. http://dx.doi.org/10.1016/j.tourman.2008.06.003

Campbell, M. C., \& Keller, K. L. (2003). Brand familiarity and advertising repetition effects. Journal of Consumer Research, 30, 292-304. http://dx.doi.org/10.1086/376800

Chaudhuri, A., \& Holbrook, M. B. (2001). The chain of effects from brand trust and brand affect to brand performance: The role of brand loyalty. Journal of Marketing, 65(2), 81-93. http://dx.doi.org/10.1509/jmkg.65.2.81.18255

Chen, C., \& Tseng, W. (2010). Exploring customer-based airline brand equity: Evidence from Taiwan. Transportation Journal, 49(1), 24-34.

Cobb-Walgreen, C. J., Ruble, C., \& Donthu, N. (1995). Brand equity, brand preference, and purchase intent. Journal of Advertising, 24(3), 25-40. http://dx.doi.org/10.1080/00913367.1995.10673481

Federal Trade Commission. (2012). FTC the green guides. Statement of basis and purpose. https://www.ftc.gov/sites/default/files/attachments/press-releases/ftc-issues-revised-green-guides/greenguidesstate ment.pdf

Goldberg, M. E., \& Hartwick, J. (1990). The effects of advertiser reputation and extremity of advertising claim on advertising effectiveness. Journal of Consumer Research, 17(2), 172-179. http://dx.doi.org/10.1086/208547

Goldsmith, R. E., Barbara A. L., \& Newell, S. J. (2000). The impact of corporate credibility and celebrity credibility on consumer reaction to advertisements and brands. Journal of Advertising, 29(3), 43-54. http://dx.doi.org/10.1080/00913367.2000.10673616

Harmann, P., Ibanez, V. A., \& Sainz F. J. (2005). Green brand effects on attitude: Functional versus emotional positioning strategies. Marketing Intelligence and Planning, 23(1), 9-29. http://dx.doi.org/10.1108/02634500510577447

Juntunen, M., Juntunen J., \& Juga J. (2011). Corporate brand equity and loyalty in B2B markets: A study among logistics service purchasers. Journal of Brand Management, 18(4), 300-311. http://dx.doi.org/10.1057/bm.2010.43

Karna, J., \& Heikki. (2001). Green advertising: Greenwash or true reflection of marketing strategies? Greener Management International, (Spring), 59-70.

Keller, K. L. (1993). Conceptualizing, measuring, and managing customer-based brand equity. Journal of Marketing, 57, (1), 1-22. http://dx.doi.org/10.2307/1252054

Lutz, R. J. (1985). Affective and cognitive antecedents of attitude toward the ad: A conceptual framework. L. A. Alwitt \& A. A. Mitchell (Eds.), Psychological Processes and Advertising Effects, Hillsdale, NJ: Lawrence Erlbaum Associates, 45-64.

MacKenzie, S. B., Lutz, R. J., \& Belch G. E. (1986). The role of attitude toward the ad as a mediator of advertising effectiveness: A test of competing explanations. Journal of Marketing Research, 23, 130-143. http://dx.doi.org/10.2307/3151660

Newell, S. J. (1993). Developing a measurement scale and a theoretical model defining corporate credibility and determining its role as an antecedent of consumers' attitude toward the advertisement. (Doctoral Dissertation). Florida State University. Tallahassee, Florida, U.S.A.

Obermiller, C., \& Spangenberg, E. R. (1998). Development of a scale to measure consumer skepticism toward advertising. Journal of Consumer Psychology, 7(2), 159-186. http://dx/doi.org/10.1207/s15327663jcp0702

Park, C. S., \& Srinivasan, V. (1994). A survey-based method for measuring and understanding brand equity and its extendibility. Journal of Marketing Research, 31(2), 271-288. http://dx.doi.org/10.2307/3152199

Parker, B. T. (2012). Candidate brand equity valuation: A comparison of U.S. presidential candidates during the 2008 primary election campaign. Journal of Political Marketing, 11(3), 208-230. http://dx.doi.org/10.1080/15377857.2012.699424 
Phelps, J., \& Thorson, E. (1991). Brand familiarity and product involvement effects on the attitude toward an ad-brand attitude relationship. Advances in Consumer Research, 18, 202-209.

Reichheld, F. F. (2001). Loyalty rules: how today's Leaders build lasting relationships. Harvard Business School Publishing Corporation.

Riley, C. (2004). Mapping out a path to hidden treasure of customer loyalty. Media, Feb. 27, 16.

Rios, R. E., \& Riquelme, H. E. (2008). Brand equity for online companies. Marketing Intelligence and Planning, 26(7), 719-742. http://dx.doi.org/10.1108/02634500810916681

Ross, S. (2006). Conceptual framework for understanding spectator-based brand equity. Journal of Sport Management, 20(1), 22-38.

Schuhwerk, M. E., \& Lefkoff-Hagius, R. (1995). Green or non-green? does type of appeal matter when advertising a green product? Journal of Advertising, 24(2), 45-54. http://dx.doi.org/10.1080/00913367.1995.10673475

Severi, E., \& Choon, L. K. (2013). The mediate effects of brand association, brand loyalty, brand image and perceived quality on brand equity. Asian Social Science, 9(3), 1911-2025. http://dx.doi.org/10.5539/ass.v9n3p125

Tong, X., \& Hawley, J. M. (2009). Measuring customer-based brand equity: Empirical evidence from the sportswear market in China. Journal of Product and Brand Management, 18(4), 262-271. http://dx.doi.org/10.1108/10610420910972783

Yasin, N. M., \& Zahari, A. R. (2011). Does family and viral marketing have any effect on brand equity? Journal of Contemporary Marketing Review, 1(9), 19-31.

Yoo, B., \& Donthu, N. (2001). Developing and validating a multidimensional consumer-based brand equity scale. Journal of Business Research, 52(1), 1-14. http://dx.doi.org/10.1016/S0148-2963(99)00098-3

Zeithaml, V. A. (1988). Consumer perceptions of price, quality, and value: A means-end model and synthesis of evidence. Journal of Marketing, 52(3), 2-22. http://dx.doi.org/10.2307/1251446

Zinkhan, G. M., \& Carlson, L. (1995). Green advertising and the reluctant consumer. Journal of Advertising, 24(2), 1-6. http://dx.doi.org/10.1080/00913367.1995.10673471

\section{(c) EY}

This work is licensed under a Creative Commons Attribution 3.0 License. 